\title{
Reducing Indoor Noise Levels Using People's Perception on Greenery
}

\author{
Christina E. Mediastika ${ }^{1}$, Floriberta Binarti ${ }^{2},{ }^{1}$ Petra Christian University, ${ }^{2}$ Atma Jaya Yogyakarta University
}

\begin{abstract}
Employees working in cubicles of open-plan offices in Indonesia were studied in regard to their perception on the ability of indoor greenery to reduce noise levels. Sansevieria trifasciata and Scindapsus sp were used. Each was placed in the cubicle and noise levels were measured without plants, with Sansevieria, and with Scindapsus in place. The meters showed very insignificant difference. However, responses to surveys indicated a perception of lower noise in the presence of greenery. This seemed to be supported by prior knowledge and preconception and may be useful in creating a "quieter" indoor environment.
\end{abstract}

Keywords - Cubicle rooms, indoor greenery, noise levels, people's perception

\section{INTRODUCTION}

Indoor noise levels in some offices could be as intolerable as those outdoors, since indoor levels are the accumulation of outdoor noise intrusion and indoor noise. There are several noise issues in open plan offices, such as speech privacy between locations which is masked by ambient noise level or the opposite; the need of higher pleasant ambient noise by means of sound systems to mask private speech [1]. These two issues should not be an issue in an ideal office environment where each employee focuses on their own work and does not disturb others by having conversation except in the meeting room. When formal discussion is required, it shall be conducted in a designated meeting room and private discussions shall be conducted somewhere else but in the office. A more important noise issue in open plan offices is the level of distraction or annoyance from either ambient or background noise which potentially split an employee's concentration between his/her job and non-job activities.

For those working in cubicles of open plan offices, the source of noise is usually more complicated than in single offices. In a single office, indoor noise may be generated by HVAC systems and office equipment such as, telephones, computers, printers and faxes. More noise sources are experienced in an open plan cubicles office, such as footsteps and speech from adjacent or far cubicles. Those working in cubicles may get privacy from visual distractions, but not from the noise of adjacent or far cubicles, as sounds easily disperse over cubicle walls. A common solution to attenuate ambient indoor noise is the installation of absorbent linings on to the wall, floor and ceiling. However, for buildings in warm humid climates, this is not an ideal option; since absorbent linings usually made of soft fabric or material may easily be dampened by the humid-air. In long-term use, humid linings may generate unpleasant odor and trigger the emergence of mould.

By this issue, usage of alternative material to reduce indoor noise levels was studied. The proposed absorbent material was indoor greenery. Nomination on usage of greenery was supported by earlier studies on outdoor noise and vegetation. $\mathrm{Li}$ et al [2] confirmed insignificant attenuation of noise annoyance at home which is below $7 \mathrm{~dB}$ by surrounding greenery. This finding is debatable since terminologies of ISO 717 Rating of Sound Insulation for Dwellings and ASTM E 966 Guide for Field Measurement of Airborne Sound Insulation of Building Facades and Facade Elements did not seem to be referred to by this research. Aylor [3] confirmed that corn crop reduced noise propagation by 5 to $6 \mathrm{~dB}$. This is similar to that of Samara et al [4] who concluded that a Pinus brutia belt of trees reduced traffic noise by $6 \mathrm{~dB}$. Bernatzky [5] marked that greater noise attenuation of $12 \mathrm{~dB}$ was offered by parks. Moreover, Pathak et al [6] revealed that $H$. rosasinensis reduced noise at both low and high frequencies of $26 \mathrm{~dB}, M$. peniculata of $20 \mathrm{~dB}, P$. roxburghi of $17 \mathrm{~dB}$ and $C$. nocturnum of $14 \mathrm{~dB}$. Findings of [3] to [6] are debatable, since they require deeper analysis on whether it was greenery or distance that reduced the noise.

The ability of vegetation to reduce noise was also studied by Costa [7] who confirmed that indoor greenery of Philodendron scandens had a significant sound absorption coefficient of 0.72 at the maximum frequency of $4000 \mathrm{~Hz}$. Wong et al [8] also revealed that such denser vertical greenery provided relatively better insertion loss than the rest of the tested greeneries. Such vertical greenery of $100 \%$ density provided a sound absorption coefficient of up to 0.5 at the maximum. Regardless of values of $\mathrm{dB}$ attenuation and sound absorption coefficient, all these studies indicated that vegetation has a capability of reducing noise. However, Mulligan et al [9] confirmed that loudness increased as the percentage of visible vegetation increased. Whilst, Watts et al [10] proved that the visual attractiveness of vegetation did not appear to benefit noise sensitivity. Renterghem et al [11] had also shown that the computational simulation of the vegetation belt was insignificant in reducing noise, ranging from below $1 \mathrm{~dB}$ up to $3 \mathrm{~dB}$.

Studies of [2] to [11] have triggered the reported study to learn more on whether sound reduction by greenery has solid findings or more to people's perception. The reported study was conducted indoors; a more controlled environment compared to those of outdoors. This was aimed to minimize factors of abrupt weather fluctuations such as wind speed, wind direction, air temperature, and humidity. The limited space of the indoor environment was also aimed to eliminate factors of distance which have significant effect on the actual noise 
attenuation. Usage of vegetation to substitute commonly used indoor linings was proposed since earlier research confirmed that greenery might improve indoor air quality by absorbing air pollution $[12,13,14]$ and may benefit as a possible solution to the global warming issue.

\section{OBJECTIVE}

There were two objectives of this study. First, it was to study whether there is any significant noise level degradation attributable to the installation of indoor greenery. The study took place in open plan cubicle offices as representation of indoor environment. Research within the controlled indoor environment was proposed to minimize non-greenery factors that may mask the noise degradation process. An open plan cubicle office was selected since occupants of this indoor environment experience potential noise annoyance. The second objective of the study was to study employees' prior knowledge, preconception and perception on the usage of greeneries. At the end, the study was expected to explain whether the actual noise reading by sound level meter correlates to noise annoyance experienced by employees.

\section{THEORETICAL APPROACH}

It is showed by studies of [2] to [11] that evidence of greenery in reducing noise is still debatable. When it is brought to deeper analysis, we may see that even though there was noise reduction during greenery, the reduction was very insignificant. It mostly ranged below $1 \mathrm{~dB}$ to $6 \mathrm{~dB}$. Sound fluctuation below 7 $\mathrm{dB}$ is off the human's auditory sensitivity $[15,16]$. Thus any noise level degradation below $7 \mathrm{~dB}$ is considerably negligible to a human. In the case when people declare of significant noise level reduction, whilst according to the measuring equipment it is very insignificant; we may suspect that it may only be of people's perception.

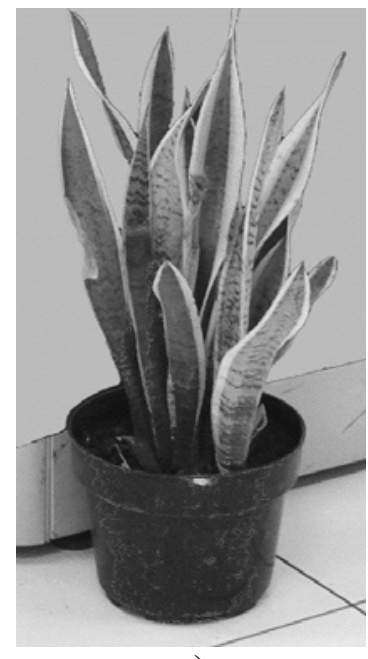

a)

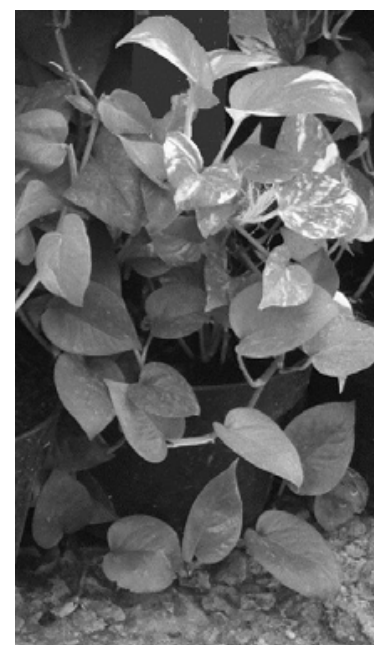

b)
Fig. 1. a) Sansevieria trifasciata and b) Scindapsus sp

Capability of greenery to absorb or reduce noise may be supported by the nature of plants that consist of leaves with unique surfaces covered by stoma and delicate hair [17]. Thus properties of plants are similar to those of absorbent linings, such as carpets and soft perforated panels commonly used in buildings. The porous surface of these objects offer significant absorption coefficient at high frequency sound [18]. Both research by Costa [6] and Wong [7] also confirmed that vegetation possesses great absorption coefficient at higher frequency. It is because sounds at low frequencies are of longer wavelength [19] which could not be absorbed by such tiny leaf and stoma. Stomas and hairs are very delicate, thus theoretically it will only have the ability to absorb high frequency noise; noise that is not entitled vibration.

To study deeper on whether plants have the capability to reduce noise or it is more due to people's preconception and perception, a study on the use of greenery in two Indonesian offices is reported here. Two types of plants that are commonly used as indoor greenery in Indonesia and are easy to maintain were selected. They were Sansevieria trifasciata and Scipdasus $s p$ (Fig.1). Sansevieria represents thick, stiff and ribbon-like leaves, whilst Scindapsus is the opposite: thin, soft and round-shaped leaves. Both are robust plants; almost independent to sun exposure and insignificant water demand. That is, the selected greeneries are suitable to be kept indoors. The Scindapsus may be kept indoors all the time, whilst Sansevieria requires sun exposure once a month for approximately one or two days and may be brought back indoor afterwards.

\section{METHODS}

The study was conducted empirical to study both the actual indoor noise levels before and during greenery and the employees' prior knowledge, preconception, and perception on greenery installation. Field measurements on ambient indoor noise and questionnaire-type surveys were conducted to collect the data. The surveys were carried out with a printed questionnaire to be filled by respondents. During the collection of filled questionnaires a checking of errors was conducted. That is, when error or bias answers were suspected, a personal interview was carried out.

Employees working in two open-plan offices were the focus of this study. They were administration officers at the Faculty of Engineering of Atma Jaya Yogyakarta University (AJYU, Fig.2 and Fig.4) and employees at Design Graphics and Mechanical Engineering Department of Alstom Power Surabaya (Fig.3 and Fig.5). The first office represented a working environment with significantly high tolerance to noise and annoyance as one of employees' job description was customer service for students and lecturers. The second office represented a more private and individual job description and thus lower tolerance to noise annoyance and distraction. Both offices were air conditioned and thus no openings existed.

At the first stage, existing noise levels within the two offices were measured. Then, the second measurement was with Sansevieria installed and the third with the Scindapsus. Each plant of approximately $80 \mathrm{~cm}$ height was planted in a medium container, with 1 container for 1 cubicle. Since Scindapsus is a 
type of climbing plant, it requires a frame to grow on a container. A timber stick of $80 \mathrm{~cm}$ height was placed on the container for the plants to climb around. It took approximately 6 months to prepare the climbing greenery and mature Sansevieria.

As in Fig.2 and Fig.4, there were 10 occupied cubicles in AJYU office. Each cubicle has direct access to 1 container. For the entire room, 18 containers were placed. Fig.3 and Fig.5 describes cubicles layout and greenery installation of the Alstom office. Here, 49 cubicles were available, but only 31 were occupied. Those without greeneries were unoccupied. The number of containers placed in the office was based on the availability of sufficient space for circulation and movement. That was limited to 18 containers in the AJYU office and 34 in the Alstom office. Any more plants was considered too tight for employees' movement and circulation.

In both offices, 3 Sound Level Meters (SLM) were installed to measure actual ambient noise levels. Three SLMs were considered sufficient to record the ambient noise of the entire room. By using 3 SLMs all together, we might control reliable data reading from one to another SLM [20]. The difference in room dimension of AJYU office which was $7.00 \times 9.50 \mathrm{~m}^{2}$ and Alstom office which was $14.00 \times 18.00 \mathrm{~m}^{2}$ resulted in a difference in where the SLMs were placed in each office. In Alstom, they were installed linearly through the main corridor which was located approximately in the middle of the room, each $4 \mathrm{~m}$ from one another. Whilst in AJYU office, they were set triangularly, each $4 \mathrm{~m}$ apart from one another. The potential noise source of this office was from the receptionist counter where employees served customers. Thus, 2 SLMs were put close to the potential source and 1 was put approximately in the middle of the room. Sound pressure levels of ambient noise were collected using conventional SLM, DEKO - Type SL 130 digital. This is a class 2 SLM (previously type 2), refers to IEC [21]. Class 2 is general purpose instruments for field use, including measurement of noise at work, with tolerances lie between the old type 1 and type 2. Tolerance for class 2 is \pm 1.3 $\mathrm{dB}$ with $\pm 0.3 \mathrm{~dB}$ included uncertainty; operated in temperature limit of $0{ }^{\circ} \mathrm{C}$ to $+40{ }^{\circ} \mathrm{C}$.

The SLMs were brand new ones and have been manufactory pre-calibrated. They stood on $120 \mathrm{~cm}$ height tripods and were set in A-weighting network reading (Fig.6). Each group of data collection was conducted in 3 working days during working hours, limited to 30 minutes after it starts and 30 minutes before it ends. Thus it was 9 days sum in each office. The first and last 30 minutes were not recorded to give sufficient time for employees to be ready for work and to prepare for leaving. This was considered as a transition time between arriving and leaving, and was notified as noisier than the rest of the day during pre-surveys. Noise during transition time was higher as employees tend to have chat amongst themselves. As the SLMs were conventional (not integrating-averaging), the reading was taken sequentially every 15 minutes after the meter was on. Operators did not stand close to SLMs during data recording as human body may reflect sound and thus generating non-valid noise recording [20]. They stood close to the meter only when collecting data from the SLMs' screen. Sequential data collection of each 15 minutes during 7 hours; means 28 recorded data; was considered to provide more actual data than that of one $\mathrm{L}_{\text {eq }}$ during 7 hours, which means 1 data only. This setting would also allow operators to have more control on the running equipment whether it worked properly, running error, or battery critical.

Along with the noise reading, questionnaires were collected from all employees in the two offices, before and during the installation of greeneries. There were 10 employees in the AJYU office and 31 in the Alstom office -- a total of 41 respondents. The questionnaire was constructed sequentially. First was to gain personal data of employees and their employment which is gender, age, and period of service. Second was the judgment on noise annoyance in the existing condition, which consists of judgment of noise levels, level of annoyance, type of noise source, and expectation on the room's improvement. Third was prior knowledge and preconception on greeneries' ability in reducing noise. Fourth was judgment on noise annoyance during installation of greenery. The first and second sequences were asked prior to placement of greenery and third and fourth were asked during the time when greeneries were placed. As this study was mostly related to numerical noise and opinion on noise, the questionnaire could not be constructed using the common Likert's scale fully. However, the questioinnaire was developed as close as possible to the Likert's scale, which is rated from the level of disagreement to agreement. Likert's scale is a widely used scaling to measure people's judgment on such issues. It usually ranges from "strongly disagree" to "strongly agree" on such issues. It is scored from 1 to 5 or 1 to 7 for more detail. One is scored for those who "strongly disagree" and 5 or 7 are for those who "strongly agree".

There were dependant and independent variables appointed to construct the questionnaire. Dependant variable was judgment on noise annoyance, both existing and during greenery installation. Whilst the independent were gender, age, period of service, level of distraction, expectation on the room's improvement, prior knowledge on greenery, preconception on greenery, and judgment on greenery installation. The last two variables were considered as variables that constructed the respondents' perception.

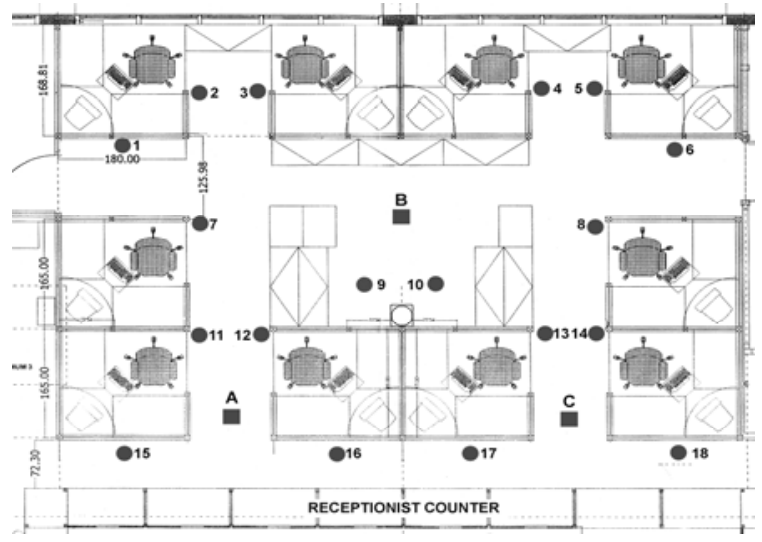

Fig. 2. AJYU's office layout plan and greenery setting, with $\bullet$ is greenery and - is Sound Level Meter 


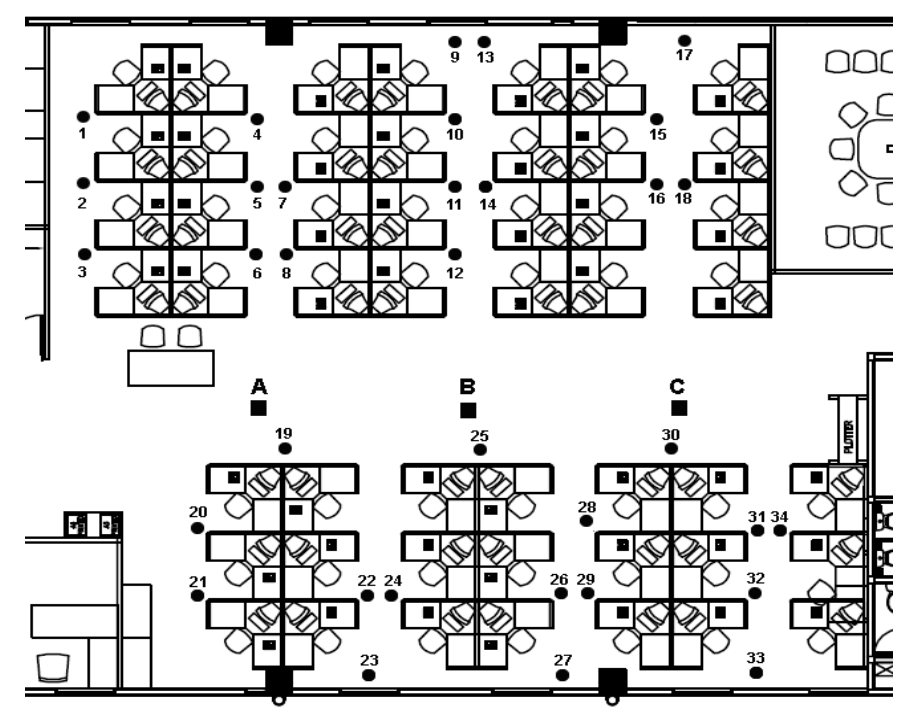

Fig . 3. Alstom's office layout plan and greenery setting, with $\bullet$ is greenery and $\boldsymbol{n}$ is Sound Level Meter. Cubicles without greenery were unoccupied

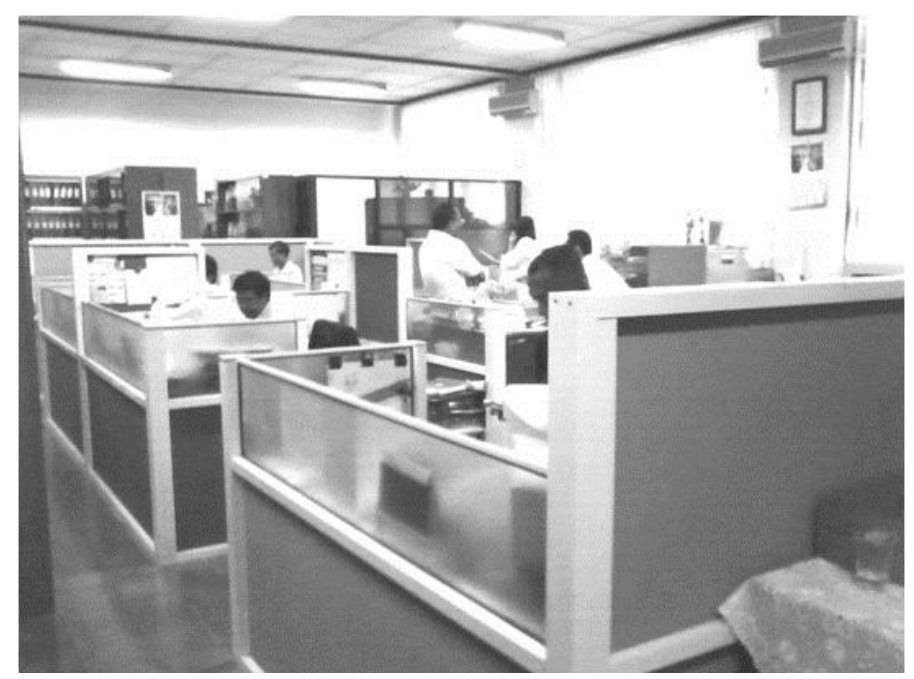

Fig. 4. View of the AJYU office

As respondents were considered having limited knowledge on noise levels, the option of answers in the second sequence were designed to offer ease in picking the answer. Options regarding ambient noise condition were modified from decibel numeric to auditory sense which was varied from "very quiet", "quiet", "fair", "noisy", to "very noisy". Options regarding indoor noise levels were also modified from decibel numeric to auditory and visual senses which was varied from "like the sound of a breeze", "like conversation", "like a scream", "like a vacuum cleaner ", "like a highway junction", to "like being adjacent to a moving train". Level of distraction was modified from "always difficult to focus" on work task, "difficult to focus", "fair", "easy to focus", to "always easy to focus".

The validity and reliability was also tested. At first, pre-questionnaires were distributed to 5 employees other than the respondents to be included in the study. This was to gain feedback to improve the questionnaire prior to the main survey. From here, several unclear statements were revised for further ease. Prior to the main analysis, answers of each question were scored and tested for their validity using statistical correlation formula.

By Table I, we found that 2 questions were not valid, thus were not to be included for further analysis. Reliability of the questionnaire was tested using Cronbach's Alpha $(\alpha)$. The $\alpha$ was 0.44 which is considered as fairly reliable [22]. Table I presents validity and reliability test and other statistical terms of the questionnaire result.

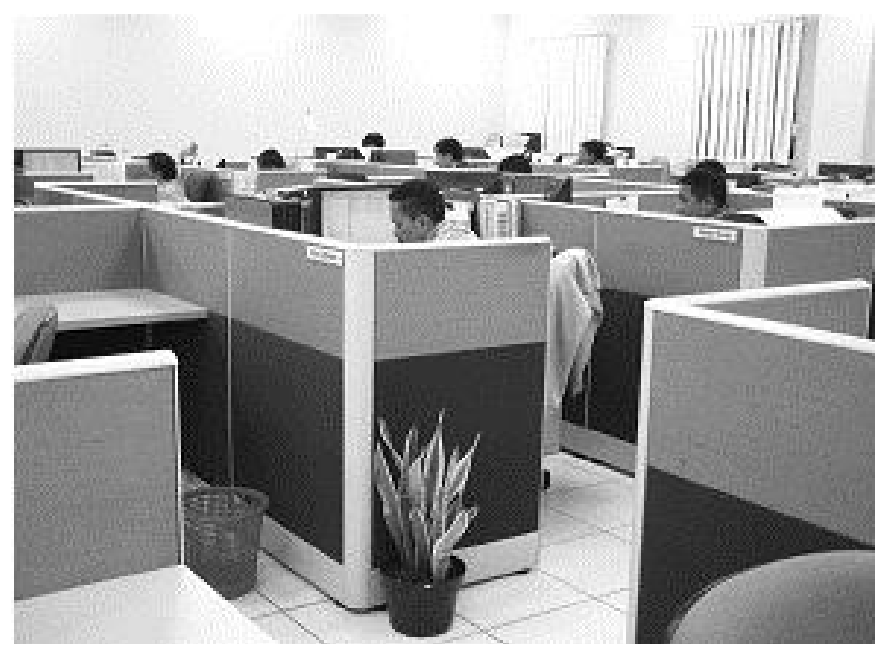

Fig. 5. View of the Alstom office

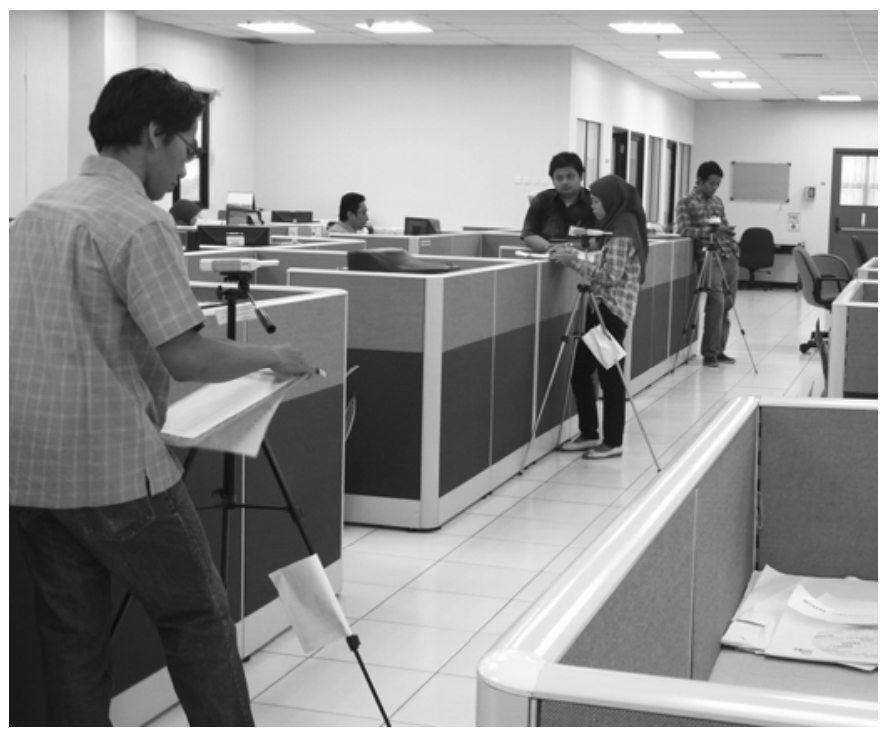

Fig. 6. SLMs setting in Alstom office 
TABLE I

STATISTICAL REVIEW OF THE RESPONDENTS' RESPONSES

\begin{tabular}{|c|c|c|c|c|c|c|c|c|c|c|c|}
\hline $\begin{array}{c}\text { Statistic } \\
\text { term }\end{array}$ & Gender & Age & $\begin{array}{l}\text { Period } \\
\text { of } \\
\text { service } \\
\end{array}$ & $\begin{array}{l}\text { Judgment } \\
\text { about } \\
\text { existing } \\
\text { noise } \\
\text { annoyance } \\
\end{array}$ & $\begin{array}{c}\text { Judgment } \\
\text { about } \\
\text { existing } \\
\text { noise levels } \\
\end{array}$ & $\begin{array}{c}\text { Level of } \\
\text { distraction }\end{array}$ & $\begin{array}{l}\text { Expectation } \\
\text { on room's } \\
\text { improvement }\end{array}$ & $\begin{array}{c}\text { Prior } \\
\text { knowledge } \\
\text { about } \\
\text { greenery }\end{array}$ & $\begin{array}{c}\text { Preconception } \\
\text { about } \\
\text { greenery }\end{array}$ & $\begin{array}{c}\text { Judgment } \\
\text { about } \\
\text { greenery } \\
\text { installation }\end{array}$ & $\begin{array}{c}\text { Judgment } \\
\text { about noise } \\
\text { annoyance } \\
\text { during } \\
\text { greenery } \\
\text { installation } \\
\end{array}$ \\
\hline Mean & 1.90 & 3.07 & 2.80 & 2.93 & 2.15 & 3.17 & 3.44 & 1.41 & 3.61 & 3.61 & 3.34 \\
\hline $\begin{array}{l}\text { Standard } \\
\text { Error }\end{array}$ & 0.05 & 0.24 & 0.20 & 0.08 & 0.12 & 0.16 & 0.15 & 0.08 & 0.11 & 0.11 & 0.07 \\
\hline Median & 2.00 & 3.00 & 3.00 & 3.00 & 2.00 & 3.00 & 4.00 & 1.00 & 3.00 & 4.00 & 3.00 \\
\hline Mode & 2.00 & 3.00 & 3.00 & 3.00 & 2.00 & 4.00 & 4.00 & 1.00 & 3.00 & 4.00 & 3.00 \\
\hline $\begin{array}{l}\text { Standard } \\
\text { Deviation }\end{array}$ & 0.30 & 1.56 & 1.25 & 0.52 & 0.79 & 1.00 & 0.98 & 0.50 & 0.70 & 0.70 & 0.48 \\
\hline $\begin{array}{l}\text { Sample } \\
\text { Variance }\end{array}$ & 0.09 & 2.42 & 1.56 & 0.27 & 0.63 & 1.00 & 0.95 & 0.25 & 0.49 & 0.49 & 0.23 \\
\hline Kurtosis & 6.24 & -0.91 & 1.68 & 0.95 & 1.78 & -0.80 & -1.03 & -1.97 & -0.63 & 0.00 & -1.60 \\
\hline Skewness & -2.82 & 0.21 & 0.87 & -0.12 & 1.31 & -0.04 & -0.33 & 0.36 & 0.72 & -0.18 & 0.69 \\
\hline Range & 1.00 & 5.00 & 5.00 & 2.00 & 3.00 & 4.00 & 3.00 & 1.00 & 2.00 & 3.00 & 1.00 \\
\hline Minimum & 1.00 & 1.00 & 1.00 & 2.00 & 1.00 & 1.00 & 2.00 & 1.00 & 3.00 & 2.00 & 3.00 \\
\hline Maximum & 2.00 & 6.00 & 6.00 & 4.00 & 4.00 & 5.00 & 5.00 & 2.00 & 5.00 & 5.00 & 4.00 \\
\hline Sum & 78.00 & 126.00 & 115.00 & 120.00 & 88.00 & 130.00 & 141.00 & 58.00 & 148.00 & 148.00 & 137.00 \\
\hline Count & 41.00 & 41.00 & 41.00 & 41.00 & 41.00 & 41.00 & 41.00 & 41.00 & 41.00 & 41.00 & 41.00 \\
\hline Largest & 2.00 & 6.00 & 6.00 & 4.00 & 4.00 & 5.00 & 5.00 & 2.00 & 5.00 & 5.00 & 4.00 \\
\hline Smallest & 1.00 & 1.00 & 1.00 & 2.00 & 1.00 & 1.00 & 2.00 & 1.00 & 3.00 & 2.00 & 3.00 \\
\hline $\begin{array}{l}\text { Confidence } \\
\text { Level } \\
(95.0 \%)\end{array}$ & 0.09 & 0.49 & 0.39 & 0.16 & 0.25 & 0.31 & 0.31 & 0.16 & 0.22 & 0.22 & 0.15 \\
\hline r Data & 0.30 & 0.72 & 0.63 & 0.41 & 0.27 & 0.34 & 0.31 & 0.37 & 0.61 & 0.23 & 0.42 \\
\hline $\mathrm{r}$ Table & 0.31 & 0.31 & 0.31 & 0.31 & 0.31 & 0.31 & 0.31 & 0.31 & 0.31 & 0.31 & 0.31 \\
\hline Validity & valid & valid & valid & valid & not valid & valid & valid & valid & valid & not valid & valid \\
\hline Reliability & 0.44 & 0.44 & 0.44 & 0.44 & 0.44 & 0.44 & 0.44 & 0.44 & 0.44 & 0.44 & 0.44 \\
\hline
\end{tabular}

\section{RESUlt AND DisCUSSION}

Continuous noise level measurements of 15 minutes each using 3 SLMs of 7 hours per day for 18 days produces hundreds of numerical data, which may lead to bias. It was 3

days for sound pressure level of the existing condition, 3 days with Sansevieria, and 3 days with Scindapsus in each office. There were 1,512 datas sum. This should be brought into one figure of $\mathrm{L}_{\text {eq }}$ of each group, which is before greenery, during Sansevieria and during Scindapsus of the AJYU office and similar to these of the Alstom office. $\mathrm{L}_{\mathrm{eq}}$ is the preferred method to describe sound levels that vary over time, resulting in a single decibel value which takes into account the total sound energy over the period of time of interest. The $\mathrm{L}_{\mathrm{eq}}$ of each group was calculated using (1) [23].

$$
L_{e q}=L_{50}+0.43\left(L_{1}-L_{50}\right)
$$

Each $\mathrm{L}_{\text {eq }}$ of 3 SLMs was then averaged statistically to represent $\mathrm{L}_{\mathrm{eq}}$ of each group. The average values of each office are presented in Fig. 7 and Fig. 8. Both figures show that there was indoor noise level reduction, but it was very insignificant. In the AJYU office, noise reduction was approximately $4 \mathrm{~dB}$, but in Alstom office, it was less, which is below $1 \mathrm{~dB}$. These differences are off audible range of human auditory sensitivity, so is impossible to physically create more comfortable noise conditions $[15,16]$. This finding was not in line with Costa [7] and Wong [8], which might be caused by different noise spectrum or frequency or lesser greenery. However, considering availability of sufficient space for movement and circulation, adding more greenery in to the room seemed impractical. Existing ambient indoor noise level of Alstom with more private and individual type of employees was found to be higher than that of noise standard in an office. The standard is $50 \mathrm{~dB}$ maximum [23], whilst it was approximately $58 \mathrm{~dB}$ in Alstom. By post-surveys, it was found that HVAC seemed to be the potential source. Ambient noise level in AJYU with more distraction of customers entering and leaving the room was surprisingly found lower than the standard. We may learn that somehow particular type and installation system of HVAC created more noise than some other types.

Interesting phenomenon is to be discussed from the questionnaire surveys result. By Fig. 9, Fig. 10 and Fig. 11, we learn that respondents were between 36 to 40 years of age as a majority. Most of them were male with a period of service within the tested room of mostly between 2 to 3 years. There 
were respondents of both offices with a period of service more than the mode and the mean, but in Alstom, this was not the case, since employees were relocated to a newer room 3 years earlier. Their judgment on the previous room was not considered in this study since the main consideration was respondents' judgment on noise annoyance in the existing room.

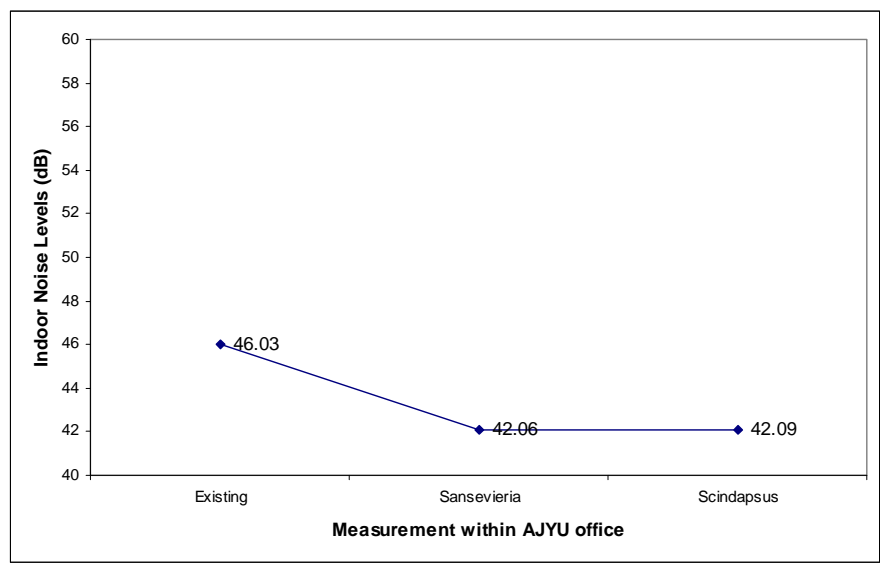

Fig. 7. Ambient indoor noise levels within AJYU office

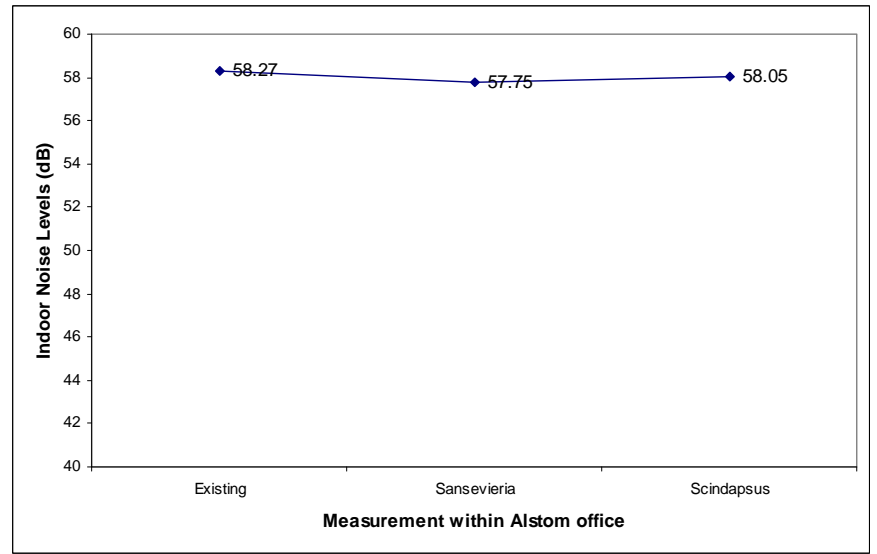

Fig. 8. Ambient indoor noise levels within Alstom office

By Fig.12 and Fig.13, we learn that most respondents judged the existing noise annoyance were categorized "fair" with "fair" level of distraction which trigger them to "easily focus" on their job description. Whilst by Fig. 14 and Fig.15, the data confirms that most respondents "do not possess prior knowledge" regarding greenery reducing noise, but the mean shows more positive result which was 0.4 point over the mode. It is interesting to find that with tiny prior knowledge, on average they had the preconception toward "convinced" that greenery has the ability to reduce noise ( 0.6 point above the mode). Specific to AJYU office, it was the mode and the mean that respondents had perception toward quieter office during installation of greenery (Fig.16). This slightly differs to that of Alstom. In Alstom the judgment was lower. It was only 0.3 point above the mode (Fig.17). But still, it shows average toward "quieter" office. Overall, we may learn that both offices show average value similar to that of Alstom's (Fig.18). That is, even in very low level, indication of perception on "quieter" office existed among respondents.

The findings of the questionnaire confirmed that perception toward a "quieter" office during placement of greenery was not supported by the metered noise levels. Respondents' perception that was not in line with the meter might be supported by their preconception on greenery's ability to reduce noise. It might also be supported by the question regarding respondents' feeling toward greenery installation. By this question, 8 respondents out of 10 in AJYU and 20 respondents out of 31 in Alstom agreed that greenery created more pleasant view within room. However, as this question was found to have insufficient validity during the correlation test (Table 1), this might not be useful for deeper analysis.

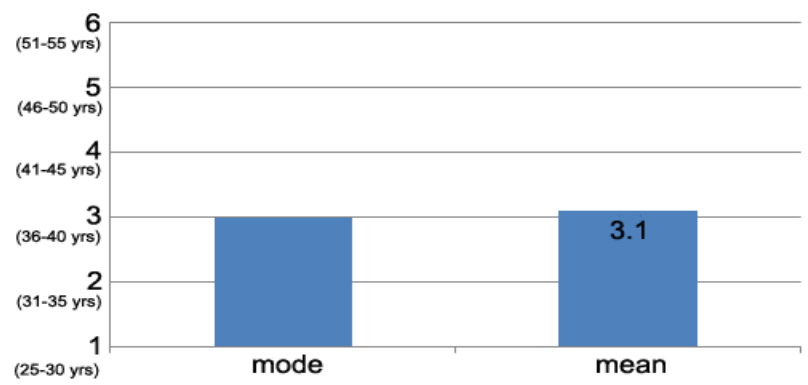

Fig. 9. Profile of respondents' age

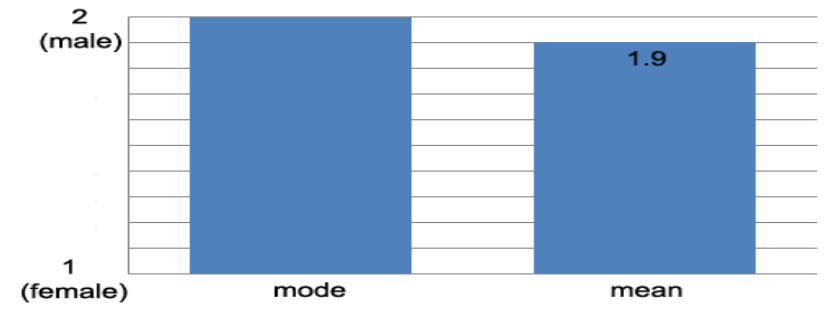

Fig .10. Profile of respondents' gender

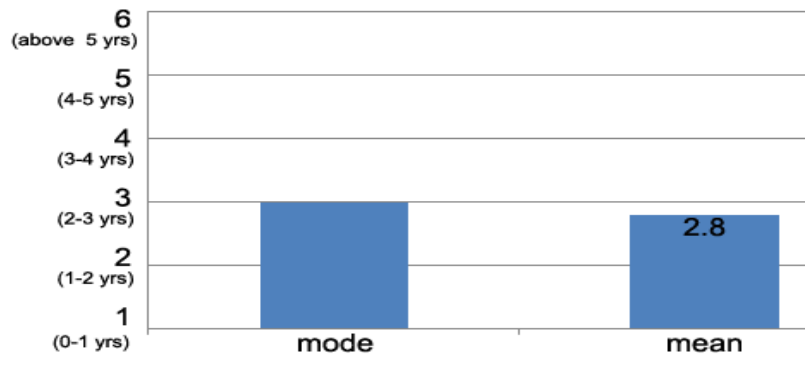

Fig. 11. Profile of respondents' period of service

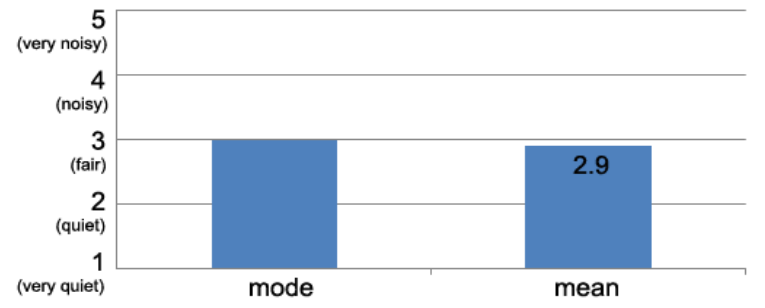

Fig. 12. Judgment about existing noise annoyance 


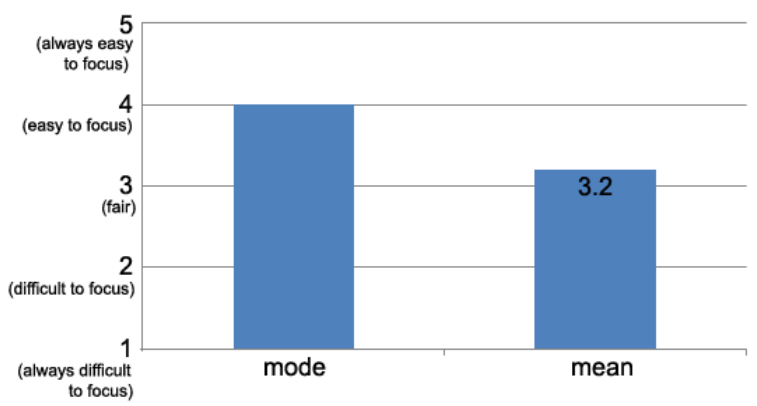

Fig. 13. Judgment about existing level of distraction

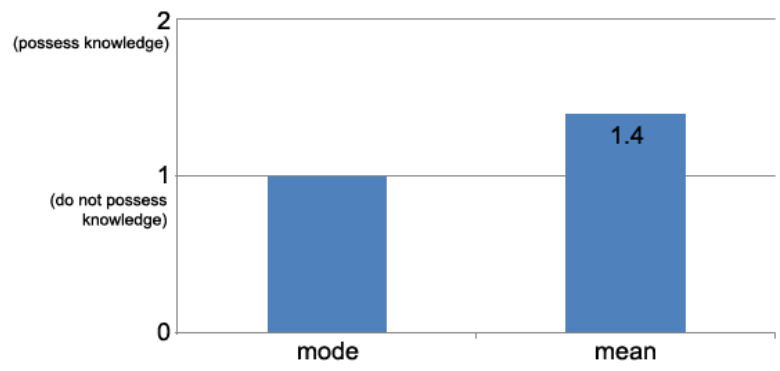

Fig. 14. Prior knowledge on greenery's ability to reduce noise

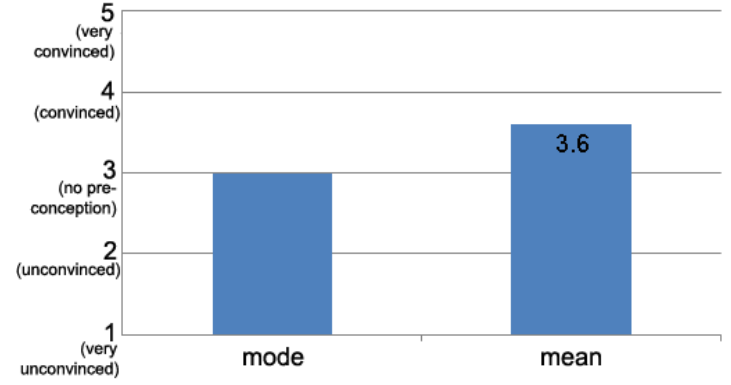

Fig. 15. Preconception on greenery's ability to reduce noise

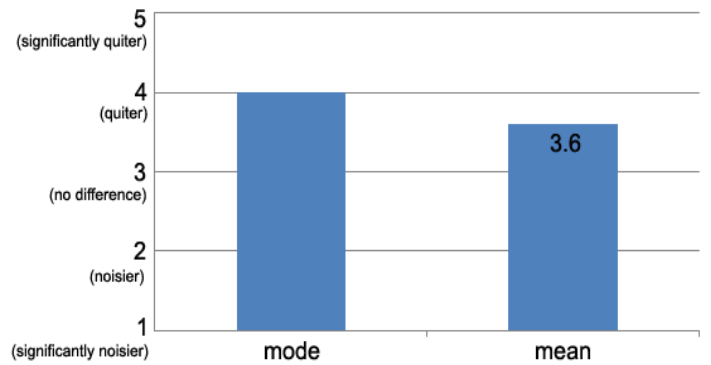

Fig. 16. AJYU office's judgment about noise annoyance during greenery

TABLE II

SCORING OF VARIABLE OF AGE IN ASSOCIATION WITH OTHER VARIABLES

\begin{tabular}{|c|c|c|c|c|c|}
\hline \multirow{2}{*}{ Age (years) } & \multicolumn{4}{|c|}{ Score } \\
\cline { 2 - 6 } & $\begin{array}{c}\text { Judgment about } \\
\text { existing noise } \\
\text { annoyance }\end{array}$ & Level of distraction & $\begin{array}{c}\text { Prior knowledge } \\
\text { about greenery }\end{array}$ & $\begin{array}{c}\text { Preconception } \\
\text { about greenery }\end{array}$ & $\begin{array}{c}\text { Judgment about noise } \\
\text { annoyance during } \\
\text { greenery }\end{array}$ \\
\hline $25-30$ & 2.56 & 2.89 & 1.22 & 3.11 & 3.11 \\
\hline $31-35$ & 3.00 & 3.50 & 1.17 & 3.33 & 3.17 \\
\hline $36-40$ & 2.90 & 3.50 & 1.40 & 3.90 & 3.40 \\
\hline $41-45$ & 3.13 & 3.00 & 1.75 & 4.13 & 3.50 \\
\hline $46-50$ & 3.20 & 2.80 & 1.60 & 3.20 & 3.60 \\
\hline $51-55$ & 3.00 & 3.33 & 1.33 & 4.00 & 3.33 \\
\hline $\begin{array}{c}\text { Range between min to max } \\
\text { score }\end{array}$ & 0.48 & 0.61 & 0.58 & 1.02 & 0.49 \\
\hline $\begin{array}{l}\text { Significance (range more than } \\
0.50 \text { is considered significant) }\end{array}$ & Not significant & Significant & Significant & Significant & Not significant \\
\hline
\end{tabular}

TABLE III

SCoring of Variable of Period of Service in Association with Other Variables

\begin{tabular}{|c|c|c|c|c|c|}
\hline \multirow{2}{*}{ Period of service (years) } & \multicolumn{4}{|c|}{ Score } \\
\cline { 2 - 6 } & $\begin{array}{c}\text { Judgment about } \\
\text { existing noise } \\
\text { annoyance }\end{array}$ & $\begin{array}{c}\text { Level of } \\
\text { distraction }\end{array}$ & $\begin{array}{c}\text { Prior knowledge } \\
\text { about greenery }\end{array}$ & $\begin{array}{c}\text { Preconception } \\
\text { about greenery }\end{array}$ & $\begin{array}{c}\text { Judgment about noise } \\
\text { annoyance during } \\
\text { greenery }\end{array}$ \\
\hline 0 to 1 & 3.14 & 3.14 & 1.57 & 3.57 & 3.43 \\
\hline 1 to 2 & 2.80 & 2.80 & 1.20 & 3.60 & 3.40 \\
\hline 2 to 3 & 2.84 & 3.24 & 1.40 & 3.52 & 3.28 \\
\hline more than 5 & 3.25 & 3.25 & 1.50 & 4.25 & 0.22 \\
\hline $\begin{array}{c}\text { Range between } \\
\text { min to max score }\end{array}$ & 0.45 & 0.45 & 0.37 & 0.73 & Not significant \\
\hline $\begin{array}{c}\text { Significance (range more } \\
\text { than } 0.50 \text { is considered } \\
\text { significant) }\end{array}$ & Not significant & Not significant & Not significant & Significant & \\
\hline
\end{tabular}

Notation:
There was no respondents with 3-4 years period of service and only 1 respondent with 4-5 years period of service were recorded during the surveys. Thus, these types were excluded from Table III to eliminate bias. 


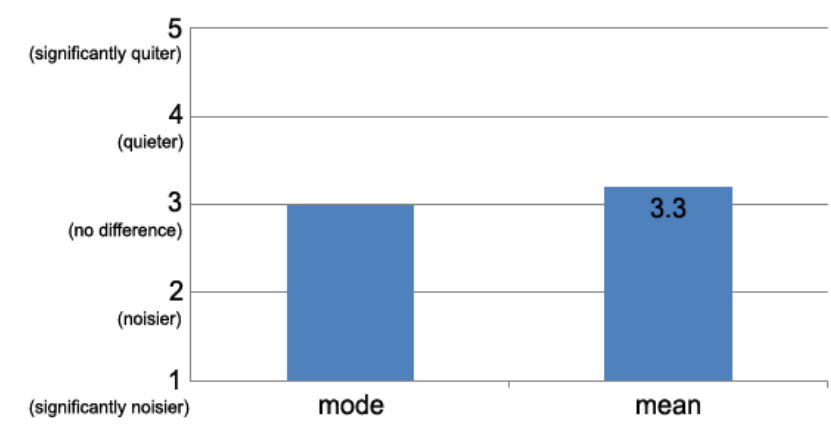

Fig .17. Alstom office's judgment about noise annoyance during greenery

Further analysis was conducted to see whether there was any correlation between gender, age, period of service and the rest variables. From the point of view of gender, there was no valid deeper analysis might be conducted since female respondents was a significant minority-- only 4 of 41 respondents. The minority would lead to a bias finding. That is to be disregarded. From age point of view (Table II, Fig. 9, Fig. 19), we may learn that variables of judgment on existing noise and judgment on noise level during greenery installation have no correlation to the age of respondents. This is marked by similar rectangles size in the bar chart with differences between min and max score below 0.50 .

Fig.19 shows a quite variation of rectangles size of level of distraction and preconception on greenery. This indicates that difference level of distraction and preconception on greenery were affected by the age of respondents. Significant difference is notified by the mode of age (36-40 years) which tends to have positive preconception than that of younger age (25-30 years) which tends to have no preconception on greenery reducing noise. From Table II, Fig.9 and Fig. 19, we may also learn that the mode felt higher level of distraction than the rest and age of 41-45 had more positive prior knowledge than the rest.

From period of service point of view, we mark that it seemed no correlation between period of service and other variables. This is represented by similar rectangles size in the bar chart and range of difference between min and max score below 0.50 ; with variable of preconception is an exception (Table III and Fig. 20). Respondents with period of service more than 5 years have more significant positive preconception than those with 2-3 years period of service, the difference was 0.73 point.

The findings of the questionnaire-type survey is interesting, since according to the meters, we may consider that there was no noise difference to respondents' auditory sensitivity, but they perceived that the noise had lowered. From this we learn that indoor greeneries may create the impression of lowered indoor noise. This perception might be supported by prior knowledge and preconception of respondents on greeneries.

There was also a question regarding respondents' expectation on the room's improvement that we may learn from. A question asked respondents whether they had any expectation on the room's improvement regarding to what they experienced currently. It was scaled from 1 to 4, which were "significantly need no improvement", "need no improvement", "need improvement" and "significantly need improvement" respectively. This question was asked before installation of greenery and the survey scored 4 as the mode, means "significantly needs improvement" (Table I). When respondents judged that existing noise annoyance was "fair", but they expected a significant improvement, the "fair" judgment might not be of actual experience. Supported by findings on metered noise levels of both offices which were over the standard, the "fairness" judgment might be based upon adaptation to existing noise. The mode data on period of service which is $2-3$ years has successfully built employees adaptation and tolerance to higher noise than they were supposed to be.

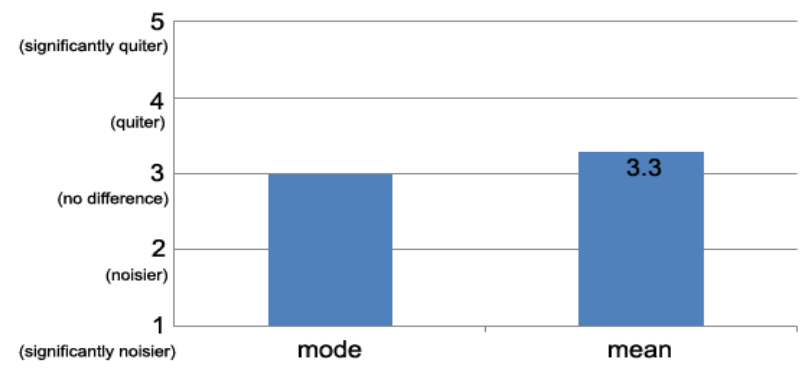

Fig. 18. Overall judgment about noise annoyance during greenery installation

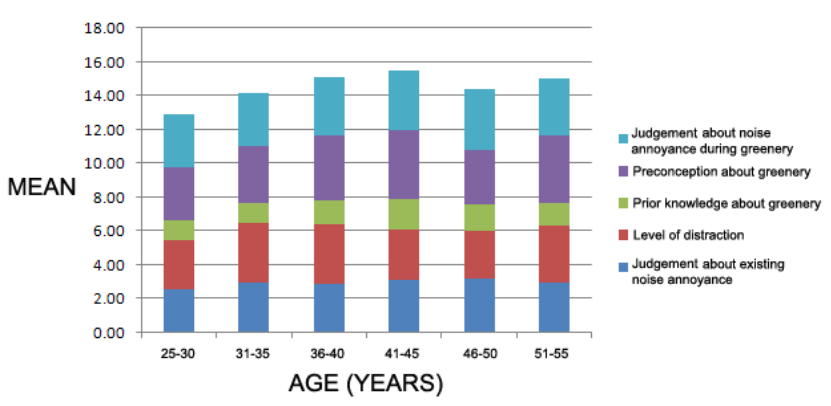

Fig. 19. Correlation between variable of age and other dependent variables

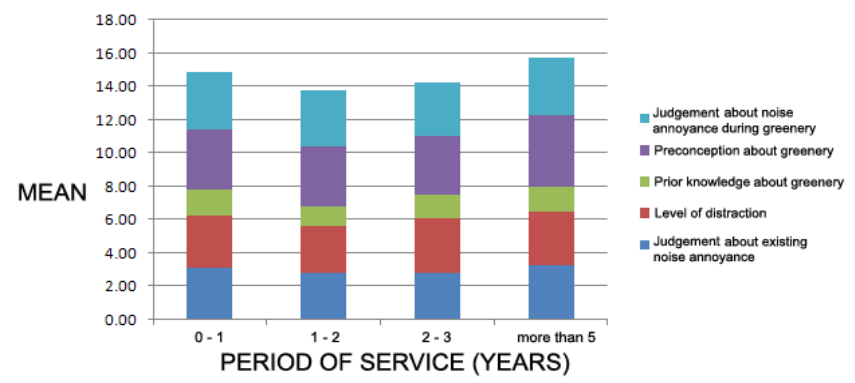

Fig. 20. Correlation between variable of period of service and other dependent variables

\section{CONCLUSION AND ReCOMmEndation}

By this study we learn that incapability of greenery to reduce noise might be masked by respondents' prior knowledge and preconception on greenery. That is, judgment on a "quieter" office by indoor greenery was merely a perception, not a factual condition. We may consider that apart from acoustical findings on greenery, respondents' perceptions on greenery may be 
useful to create more acceptable ambient indoor noise levels in open plan working spaces.

Further research to study more detail on the existence of direct and significant correlation among prior knowledge, the preconception on greenery and perception of indoor noise levels is recommended.

\section{ACKNOWLEDGEMENT}

The authors would like to express deepest gratitude to Directorate of Higher Education of Ministry of National Education and Culture of Republic of Indonesia for providing grant under scheme of "Hibah Kompetensi" to carry out this research.

\section{REFERENCES}

1. ASTM E1130 - 08 Standard Test Method for Objective Measurement of Speech Privacy in Open Plan Spaces Using Articulation Index

2. H.N. Li, C. K. Chau and S. K. Tang, Can Surrounding Greenery Reduce Noise Annoyance at Home?, Science of the Total Environment, Vol. 408, 2010, pp. 4376- 4384.

3. Aylor, Donald, Noise Reduction by Vegetation and Ground, J. Acoustic. Soc. Am, Vol. 51 Issue 1B, 1972, pp 197-205

4. Samara, Theano and Tsitsoni, Thekla, the Effect of Vegetation in Reducing Traffic Noise from A City Ring Road, Noise Control Engineering Journal, Vol. 59 No.1, January 2011, pp 68-74

5. Bernatzky, Aloys, the Contribution of Trees and Green Spaces to A Town Climate, Energy and Buildings, Vol. 5, Issue 1, September 1982, pp $1-10$

6. Pathak, V, Tripathi, BD, and Misra, VK, Dynamics of Traffic Noise in A Tropical City Varanasi and Its Abatement through Vegetation, Environmental Monitoring and Assessment, Vol. 146 Issue 1-3, November 2008, pp 67-75

7. Costa, P., and James, RW, Environmental Engineering Benefits of Plants, Workplace Comfort Forum Seminar, South Bank University, London, UK, November 1995, pp. 7-8.

8. Wong, NY, et al, Acoustics Evaluation of Vertical Greenery Systems for Building Walls, Building and Environment, Vol. 45 issue 2, February 2010, pp 411-420

9. Mulligan, BE, et al, Enhancement and Masking of Loudness by Environmental Factors, Environment and Behavior, Vol. 19 No. 4, July 1987, pp 411-443

10. Watts, G, Chinn, I, and Godfrey, N, the Effect of Vegetation on the Perception of Traffic Noise, Applied Acoustics, Vol. 56 Issue 1, January 1999, pp 39-56

11. Renterghem, TV, Botteldooren, D, and Verheyen, $\mathbf{K}$, Road Traffic Noise Shielding by Vegetation Belts of Limited Depth, J. Sound and Vibration, Vol. 331 Issue 10, May 2012, pp 2404-2425

12. Velesan, M., Sattler M. A., Green Walls and Their Contribution to Environmental Comfort: Environmental Perception in a Residential Building, Proceedings of 25th Conference on Passive and Low Energy Architecture, Dublin, October 2008

13. Bonem, M.L. Scheff, P.A. Deposition of Nitrogen Dioxide to Porous Biological Surfaces, Proceedings of IAQ Conference The Human Equation: Health and Comfort, 1989.

14. Mediastika C.E., , the Use of Fencing Plants to Reduce Particulate Matter Pollution into Indoor Environment, Journal Dimensi Arsitektur, Surabaya Indonesia, Vol.30 Issue 2, December 2002, pp. 159-166
15. Stein, B, et al, Mechanical and Electrical Equipment for Building, $7^{\text {th }}$ Ed., Canada: John Wiley and Sons, 1986, p. 1235

16. McMullan, Randal, Noise Control in Buildings, Oxford: BSP Professional Books, 1991, p.9

17. Fahn, A., Plant Anatomy, England, UK: Pergamon Press, 1990, pp. 208-248

18. Harris, Cyril M. , Acoustical Properties of Carpets, Journal Acoustic Soc. Am, Vol. 27, Issue 6, pp. 1077-1082.

19. White, R.G. and J.G. Walker, Noise and Vibration, England, Ellis Horwood Ltd., 1982, pp. 389-399

20. Chuniff, Patrick F, Environmental Noise Pollution, Canada, John Wiley and Sons, 1977, pp 57-58

21. International Standard of International Electrotechnical Commissions IEC 61672-1:2002. Sound level meters - Part 1: Specifications.

22. Urdan, Timothy C, Statistic in Plain English, New York, Routhledge, 2010, pp. 178-180

23. Mediastika, CE, Akustika Bangunan, Jakarta, Penerbit Erlangga, 2005, pp. $30-33$

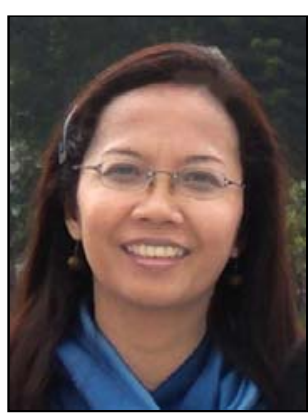

Christina Eviutami Mediastika was born in Yogyakarta Indonesia October 19, 1971. Studied in Gadjah Mada University for diploma in architecture (1995) and University of Strathclyde Glasgow $\mathrm{UK}$ for $\mathrm{PhD}$ in architecture and building science (2000).

She is a full-time lecturer in Atma Jaya Yogyakarta University Indonesia (1995-2012) and Petra Christian University Surabaya Indonesia (2013-current). Her books are Akustika Bangunan, Jakarta, Indonesia, Penerbit Erlangga, 2005; Material Akustik, Yogyakarta, Indonesia, Penerbit Andi, 2009; and Hemat Energi dan Lestari Lingkungan, Yogyakarta, Indonesia, Penerbit Andi, 2013. Her research interests are acoustic buildings, environment, and sustainable buildings.

Address: Department of Architecture, Petra Christian University, Jalan Siwalankerto 121-131, Surabaya, Indonesia 60236.

Phone: +62 312983110 Fax: +62 312983111

Email: eviutami@petra.ac.id

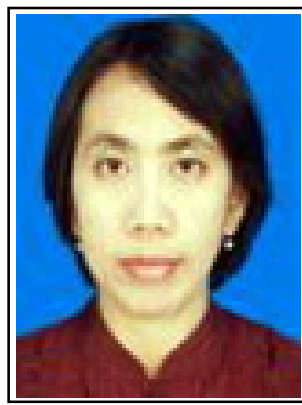

Floriberta Binarti was born in Yogyakarta Indonesia September 20, 1963. Studied in Gadjah Mada University for diploma in architecture (1993) and University of ETH Zurich for Dipl. NDS Arch (2001).

She is a full-time lecturer in Atma Jaya Yogyakarta University Indonesia (1994-current). Her publication is Interlayer and Cavity Contribution to Create High Light-to-Solar-Gain-Ratio Glass Block from Waste Glasses, International Journal of Sustainable Building Technology and Urban Development, Vol. 4, No. 1:82-88. Her research interests are acoustic buildings and lighting.

Address: Department of Architecture, Atma Jaya Yogyakarta University, Jalan Babarsari 44 Yogyakarta, Indonesia 55281.

Phone: +62 274487711 Fax: +62 274487748

Email: flo.binarti@gmail.com 